\title{
River-specific effects of the invasive amphipod Dikerogammarus villosus (Crustacea: Amphipoda) on benthic communities
}

\author{
Claudia Hellmann • Franz Schöll • Susanne Worischka • \\ Jochen Becker • Carola Winkelmann
}

Received: 16 March 2016/Accepted: 25 September 2016/Published online: 7 October 2016

(C) The Author(s) 2016. This article is published with open access at Springerlink.com

\begin{abstract}
The invasive amphipod Dikerogammarus villosus is assumed to threaten native biodiversity in rivers. In spite of small-scale experiments and field observations, its impact on natural communities is largely unknown because it seems to be variable and long-term analyses are rare. We analysed long-term data from the Upper Elbe and Middle Rhine (Germany) for invasion patterns and changes in the community structure. In addition, mesocosm experiments were performed in both rivers to identify density effects of $D$. villosus on the communities. We assumed that $D$. villosus is a driver of changes in the macroinvertebrate community and that effects are river-specific due to differing benthic communities. We found two invasion patterns for D. villosus with fast invasion in the River Elbe and slower invasion in the River Rhine. The impact of D. villosus on the
\end{abstract}

Electronic supplementary material The online version of this article (doi:10.1007/s10530-016-1286-z) contains supplementary material, which is available to authorized users.

C. Hellmann $(\bowtie) \cdot$ S. Worischka $\cdot$ J. Becker

C. Winkelmann

Institute of Integrated Natural Sciences, University

Koblenz-Landau, Universitätsstrasse 1, 56070 Koblenz,

Germany

e-mail: hellmann@uni-koblenz.de

S. Worischka

e-mail: susanne.worischka@tu-dresden.de

J. Becker

e-mail: jochenbecker@uni-koblenz.de species composition was weak in both river communities. Invasion seems to have reduced taxa number and individuals and increased Shannon diversity in the River Rhine, but not in the River Elbe. The correlations between the densities of the invader and other taxa in the long-term data were mostly positive with the exception of two native taxa in the River Rhine, indicating a lack of strong negative species interactions. Also in the mesocosm experiments, the biomass gradient of $D$. villosus adults did not cause significant changes in the communities. The community in the River Rhine seemed to be more vulnerable to the $D$. villosus invasion than that in the River Elbe. This might be caused by a dominance of invasive species interacting positively with one another, as suggested by the 'invasional meltdown' theory. The study suggests that community-level effects of invasion may differ between rivers, probably due to differences in the community composition.

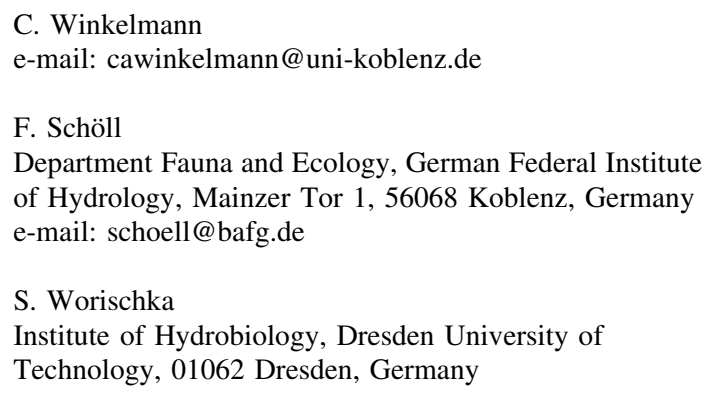


Keywords Invasion - Dikerogammarus villosus . German rivers · Benthic monitoring · River Rhine · River Elbe

\section{Introduction}

Invasion of non-native species is considered a threat to native biodiversity because invaders are often superior competitors and can therefore replace natives (Ricciardi and MacIsaac 2000; Sala et al. 2000). A growing frequency of new invasions due to increasing transport is even suspected to result in a positive feedback, called 'invasional meltdown', i.e., each successful invasion facilitates new invasions due to positive interactions between the newly arriving and already established invasive species. This might increase the impact of invasions on native communities (Simberloff and Von Holle 1999).

The amphipod Dikerogammarus villosus (Sowinski, 1894) is one of the most successful invaders of large European rivers, which probably first occurred in the Rhine system after opening the Main-Danube Canal in 1992 (Leuven et al. 2009). It has rapidly colonized most European river systems (bij de Vaate et al. 2002) and has recently invaded the British Isles (MacNeil et al. 2012). Range extension within European rivers is still going on (Boets et al. 2014) and the invasion of further freshwater systems around the world is predicted (Gallardo and Aldridge 2013). In many of the newly invaded habitats, D. villosus rapidly reaches very high densities and is able to replace or reduce native species (Dick and Platvoet 2000; Bollache et al. 2004; Noordhuis et al. 2009; Rewicz et al. 2014; Schöll et al. 2015). Dikerogammarus villosus is an omnivorous species, which has been observed to display a highly aggressive behaviour and to prey on various invertebrate taxa in laboratory experiments (Dick et al. 2002; MacNeil et al. 2013). Due to a high degree of habitat overlap of D. villosus with other native and non-native amphipods, it is assumed to threaten their populations due to its predatory behaviour (Devin et al. 2003).

It is very difficult, however, to verify the invasion of D. villosus as the principal cause for the loss of native biodiversity or the decline of single species. Field studies, partly long-term studies, detected significant changes in benthic macroinvertebrate communities coinciding with the time of the $D$. villosus invasion (Bollache et al. 2004; Josens et al. 2005; Noordhuis et al. 2009; Boets et al. 2011; MacNeil et al. 2013). This sometimes involved a drastic decline or even a local extinction of native amphipods (Dick and Platvoet 2000). However, it is often difficult to estimate the magnitude of the community change caused by $D$. villosus in relation to natural oscillations of benthic densities on the basis of a limited number of samples (e.g. van Riel et al. 2006). Larger data sets, which include longer time periods or larger spatial scales, indicate that influences of other environmental factors cannot be ruled out (MacNeil et al. 2013). In small-scale experiments, on the other hand, which allow the analysis of the direct effects of $D$. villosus on potential prey and competitors, the spatial scale and heterogeneity are often reduced drastically (e.g. Buric et al. 2009, Kinzler et al. 2009, Truhlar et al. 2014). The results of such laboratory experiments can therefore not be directly transferred to the ecosystem scale (Carpenter 1996; Schindler 1998; Englund and Cooper 2003). In addition, the invasive amphipods seem to be very opportunistic and have an extremely broad behavioural repertoire (Rewicz et al. 2014) enabling them to show different behaviours under different conditions. Although it has been clearly shown that $D$. villosus is able to prey on a wide range of relatively large prey (Dick et al. 2002; Boets et al. 2010), this predatory potential seems not always to be realised in a natural environment (Koester and Gergs 2014; Hellmann et al. 2015; Koester et al. 2016). This might explain the observation of a state of coexistence between $D$. villosus and other amphipods in some habitats (Kley and Maier 2005; Boets et al. 2011). The invaders' predation impact on benthic invertebrates appears to be very variable in natural communities and to depend on the community structure itself (Hellmann et al. 2015). Dikerogammarus villosus can prey intensively on other invasive species when they are also available in high densities whereas many native species seem to be hardly used as prey (Hellmann et al. 2015). Stable isotope analyses indicated the trophic positions of $D$. villosus in aquatic food webs to represent a primary consumer as well as a predator, but most often an omnivore (van Riel et al. 2006; Brauns et al. 2011; Bacela-Spychalska and van der Velde 2013; Hellmann et al. 2015). The methodological problems of investigations combined with the high behavioural flexibility of $D$. villosus complicate the 
analysis of its influence on the benthic communities of European rivers. Thus, although the threat is recognized, there remains debate about the strength of any negative impact of $D$. villosus invasion on aquatic biodiversity or benthic community structure in European rivers (MacNeil et al. 2013). The observed variability in the behaviour of $D$. villosus leads to the assumption that the direct effects of the invader, especially negative ones, on benthic invertebrates also strongly depend on the community structure at a specific site.

In this study, we therefore combined long-term monitoring of benthic community composition with a field mesocosm experiment to identify the direct impact of $D$. villosus on the river communities at specific sites of two large European rivers, Elbe and Rhine. We aimed to relate the observed effects on the benthic communities of two river sites to the respective invasion histories, and to the response of the benthic community in two mesocosm experiments to assess the relevance of the experimental results for the whole ecosystem. The monitoring data served to analyse the resident community structures before and after the invasion events along a gradient of $D$. villosus density. In the two mesocosm experiments, we manipulated $D$. villosus densities under near-natural conditions in the Rivers Elbe and Rhine. We tested the hypotheses that $D$. villosus would (1) induce changes in the macroinvertebrate composition, (2) reduce the density of native taxa and (3) promote other invaders.

\section{Methods}

Long-term field survey

The benthic macroinvertebrate communities in each of the two rivers were monitored by sampling with a crane fitted with a grab (Tittizer and Schleuter 1986) along a longer river section (Upper Elbe: river-km 0-65; Middle Rhine: river-km 551-643) at different transversal positions (from riversides to midstream, seven positions). The samples were taken from a wide range of different substrates with grain sizes from 0.9 to $250 \mathrm{~mm}$. The sampling was conducted annually from 1992 to 2013 in the River Elbe (except 2000, 2010 and 2012) and from 1990 to 2013 in the River Rhine (except 2007 and 2011), mostly during May to July. In total, 421 benthic samples were taken from a
$65 \mathrm{~km}$ stretch in the Upper Elbe between the GermanCzech border and the city of Dresden, and 898 samples were taken from a $92 \mathrm{~km}$ stretch in the Middle Rhine between the cities of Oberwesel and Bonn.

Mesocosm experiments

The five-week field mesocosm experiments with different initial $D$. villosus densities were started on 4th September 2012 in the River Elbe and on 17th October 2013 in the River Rhine. We exposed three floating mesocoms $(4.80 \times 2.50 \mathrm{~m})$ each consisting of three flumes (length $4.80 \mathrm{~m}$, width $0.30 \mathrm{~m}$, height $0.70 \mathrm{~m}$, high-grade steel; Fig. 1). The mesocosms were positioned between the riverside and midstream (distance to shore approx. $20 \mathrm{~m}$ ) in a row with a distance of at least $200 \mathrm{~m}$ from each other in flow direction to reduce possible interaction between the mesocosms. The specific experimental sites were chosen to roughly correspond to the sampled river stretches in the previous field surveys, in the River Elbe at $66 \mathrm{~km}$ in the city of Dresden (coordinates $51.09415 \mathrm{~N}, 13.65110 \mathrm{E}$ ) and in the River Rhine at $560 \mathrm{~km}$ near the city of St. Goar (coordinates $50.16987 \mathrm{~N}, 7.66981 \mathrm{E}$ ). The floats were anchored to the river bed, allowing surface river water to flow through the flumes. Each flume was filled end-to-end with eight high-grade steel baskets $(50 \times 20 \times 20 \mathrm{~cm}, 20 \mathrm{~mm}$ mesh size $)$ containing the typical stony substrates of the river sites (coarse gravel to hand-sized stones; Fig. 1).

The substrate-filled baskets were exposed on the river bed for 4-6 weeks prior to the start of the experiments to allow colonization by benthic organisms. After the exposure period, the colonized baskets were lifted from the river bed and transferred into the flumes. Both ends of the flumes were equipped with $2 \mathrm{~mm}$ wire mesh in the River Rhine and $16 \mathrm{~mm}$ wire mesh in the River Elbe to reduce the migration of organisms to and from the rivers. The larger mesh size in the River Elbe was chosen because of the lower current velocity and the higher particle transport than in River Rhine to allow a better water exchange between the flumes and the river. At the start of the experiments, the density of $D$. villosus in the flumes was experimentally adjusted to represent one of three treatments. One of the three flumes of each mesocosm was cleared of D. villosus as far as possible (treatment 'low'). In another flume, the D. villosus density 
A

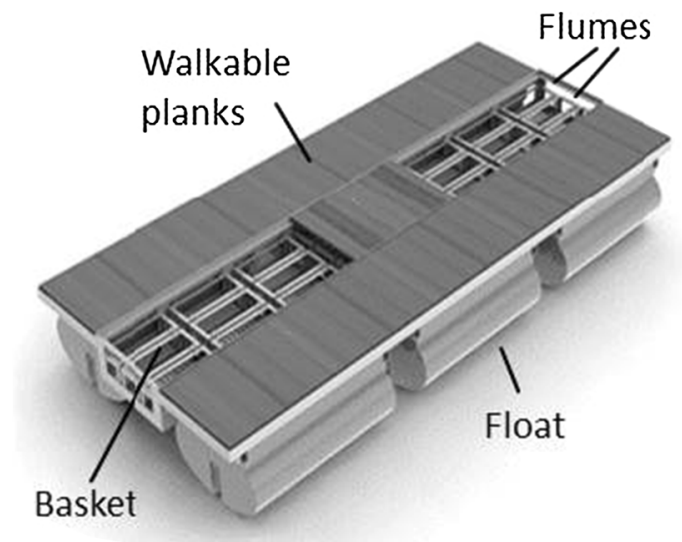

B

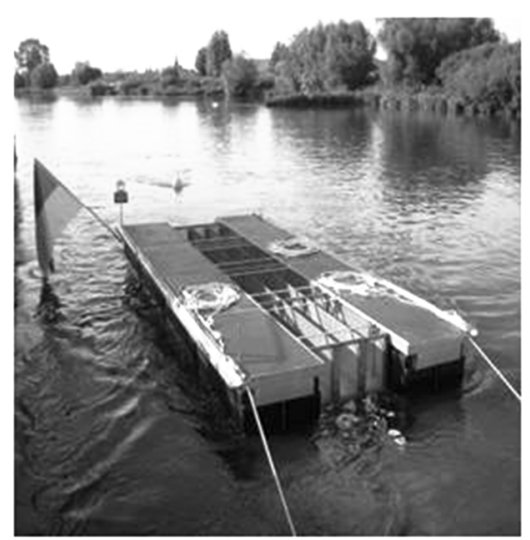

C

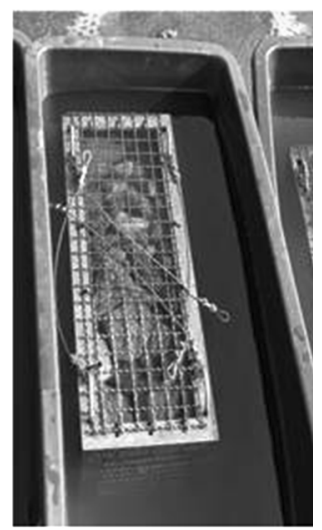

Fig. 1 Setup of the mesocosm floats (a), exposition of the floats in the river (b), and basket fulfilled with substrate (c)

remained unchanged (treatment 'control') and the density of the third flume was doubled compared to the control (treatment 'high'). For this purpose, all baskets from the treatment 'low' were emptied into large water-filled plastic containers and the flumes were cleaned to remove any remaining animals. Individuals of all sizes of $D$. villosus were separated quickly but carefully from the substratum and were kept to stock the treatment 'high' with D. villosus. The elimination of very small individuals was sometimes incomplete due to their hiding behaviour and difficulties in distinguishing them from other amphipod species. After eliminating $D$. villosus as far as possible, the baskets were refilled with the processed substratum and repositioned into the flumes. The remaining animals (except $D$. villosus) were immediately and carefully added to the baskets in the flumes. During manipulation, both ends of the flumes were closed to reduce the current velocity in order to prevent the animals from drifting downstream and to allow them to resettle quickly in the substratum instead. In the treatment 'high' and 'control', baskets were also emptied into plastic containers but refilled into the baskets without sorting the invertebrates. Thereafter, the $D$. villosus individuals previously removed from the flume with 'low' treatment were added to the treatment 'high', resulting in an approximately double density in comparison to the treatment 'control' (without the addition of D. villosus). Due to the high handling effort and to minimize stress for the animals, the manipulation was performed on-site at the three mesocosms on three consecutive days (1 day for each mesocosm). Possible influences on other macroinvertebrates and the loss of individuals due to the manipulation were kept mostly equally and as low as possible within all treatments by cautious and similar handling of all baskets (similar except for the sorting of the D. villosus). Multiple comparison tests (using Bonferroni method) indicated effects on other frequent invasive crustacean species in River Rhine with slightly lower densities in the treatment 'low' than in the treatments 'high' or 'control' at the start of the experiment (Chelicorophium spp.: 'control' vs. 'low' $p=0.08$, Echinogammarus ischnus: 'high' vs. 'low' $p=0.02$; Jaera sarsi: 'high' vs. 'low' $p=0.01$, 'control' vs. 'low' $p=0.01$ ). The differences are mainly assumed to be due to mistakes in the sorting of small individuals (E. ischnus) or the not fully preventable stress for small individuals during the sorting process.

Macroinvertebrate biomasses were estimated by sampling two randomly selected baskets from each flume 5 weeks after the initial manipulation (Elbe: 09.10.2012; Rhine: 19.11.2013). The outermost baskets at both ends of the flumes served to buffer possible side effects and were not sampled for benthic analyses. For quantitative sampling, flumes were closed at both ends and around each sampled basket using steel sheets to prevent animals from escaping from the sampling unit to the neighbouring baskets. The baskets were then transferred into individual water-filled plastic containers and all animals were removed from the substratum by washing the sediment. All animals remaining in the flume within the 
sampling compartment were removed by pumping the water over a $0.5 \mathrm{~mm}$ mesh. The benthic samples were preserved in $80 \%$ ethanol.

During the experiments, the wire meshes at both ends of the flumes were cleaned at least two times a week. Care was taken that no animals escaped during cleaning. Therefore, both ends of the flumes were closed with steel sheets for a few minutes during cleaning. The environmental conditions in all flumes were monitored at every maintenance and sampling event and were similar for the three treatments (Table 1).

\section{Sample and data analysis}

In all benthic samples, macroinvertebrates were identified to the lowest practical taxonomic level and counted. For the mesocosm experiments, the body length (or head width if necessary) of the individuals was additionally measured to the nearest $0.1 \mathrm{~mm}$ for biomass calculation. In the case of very large numbers of specimens per sample, only a sub-sample representing a quarter or an eighth of the sample was processed and only 50-100 individuals of each taxon were randomly measured. Due to their large number, amphipods were always measured from a sub-sample only. The benthic biomass per basket in the mesocosm experiments was calculated using species-specific length-dry weight relationships (Meyer 1989; Benke et al. 1999; Baumgärtner and Rothhaupt 2003; Hellmann et al. 2013, 2015).

All statistical analyses were performed with the software package R (R Development Core Team 2014). In the field survey, for comparison of the species composition before and after the D. villosus invasion a multivariate permutation test based on the Bray Curtis similarities (function anosim, R package vegan) was applied after a fourth-root transformation of the abundances to reduce the effect of dominant taxa (Anderson 2001). To visualize the change of community composition over time (20-25 years) by means of non-metric multidimensional scaling (nMDS), the species abundances of all samples of the specific year were averaged to achieve more clarity. A subset of samples beginning from the first year of $D$. villosus occurrence in each river was used to evaluate the impact of $D$. villosus density on benthic community composition. For this analysis, all samples with more than 100 individuals $\mathrm{m}^{-2}$ in total or more than three taxa were included in the data set. By the exclusion of the other samples we aimed to reduce the variability due to extremely unfavourable habitat conditions. In this subset, the similarities of the community composition excluding $D$. villosus (fourth root transformed abundances) between sampling dates were analysed by nMDS based on the Bray Curtis similarities. The influence of the available spatial ('sampling location' represented by river-km) and temporal variables ('sampling year'), in addition to 'D. villosus density' in each sample on the community composition was analysed by the function envfit (R package vegan, 999 permutations, Oksanen 2013), which is used to fit environmental vectors to an ordination. The influence of the relevant predictors on the variability of the community composition based on the envfit analysis was examined by a distance-based redundancy analysis (db-RDA; Legendre and Anderson 1999) using the Bray Curtis distance measure. To identify significant changes in community-related indicators (e.g. Shannon diversity, taxa number, total number of individuals, proportion of native taxa) due to $D$. villosus invasion, the long-term data were split into different periods depending on the first occurrence of the invader in the samples (before and after its first occurrence) or on the intensity of invasion (no, low and high occurrence), and permutation tests (1000 iterations) between the invasion periods were performed. Shannon diversity (based on the natural logarithm) was calculated from the abundance data using the software Primer 6. Species-specific effects of the different $D$. villosus densities were tested in the data set after the invasion using non-parametric Kendall's rank correlations between the densities of D. villosus and the densities of other species. The samples were selected considering the same criteria as for multivariate analyses. To identify the most important species for the community composition during the different periods of $D$. villosus invasion (i.e. indicator species), the approach of Dufrêne and Legendre (1997) implemented in the function indval ( $\mathrm{R}$ package labdsv, Roberts 2015) was used for the long-term field data. Only species with indicator values $>0.3$ were included to test the effects of $D$. villosus density on species densities.

In the mesocosm experiments, there was a fast and non-linear adjustment of $D$. villosus biomasses in the manipulated flumes to the control due to individual growth, reproduction and organismic drift, which 
Table 1 Experimental environmental conditions in the flumes with the density treatments 'control', 'low', 'high' in the mesocosms in the rivers Elbe and Rhine (means of 4-5- weeks $\pm \mathrm{SD}, \mathrm{n}=$ number of measurements during the experiments, statistics show the results of one-way ANOVA's, n.s. = nonsignificant)

\begin{tabular}{|c|c|c|c|c|c|}
\hline Abiotic measures & Control & Low & High & $\mathrm{n}$ & Statistics \\
\hline \multicolumn{6}{|l|}{ River Elbe } \\
\hline Flow velocity $\left(\mathrm{m} \mathrm{s}^{-1}\right)$ & $0.22 \pm 0.03$ & $0.23 \pm 0.03$ & $0.23 \pm 0.03$ & 11 & $\mathrm{~F}=0.107$, n.s. \\
\hline Oxygen content $\left(\mathrm{mg} \mathrm{L}^{-1}\right)$ & $10.82 \pm 0.22$ & $10.86 \pm 0.18$ & $10.84 \pm 0.22$ & 5 & $\mathrm{~F}=0.048$, n.s. \\
\hline Oxygen saturation $(\%)$ & $114.3 \pm 9.1$ & $114.4 \pm 9.6$ & $114.2 \pm 9.2$ & 5 & $\mathrm{~F}=0.0004$, n.s. \\
\hline Ion conductivity $\left(\mu \mathrm{S} \mathrm{cm}{ }^{-1}\right)$ & $421.1 \pm 8.4$ & $421.2 \pm 8.3$ & $421.1 \pm 8.3$ & 5 & $\mathrm{~F}=0.0004$, n.s. \\
\hline $\mathrm{pH}$ value & $7.97 \pm 0.36$ & $7.96 \pm 0.36$ & $7.93 \pm 0.33$ & 4 & $\mathrm{~F}=0.016$, n.s. \\
\hline Temperature $\left({ }^{\circ} \mathrm{C}\right)$ & $16.9 \pm 2.6$ & $16.9 \pm 2.6$ & $16.9 \pm 2.6$ & 5 & $\mathrm{~F}=0.0004$, n.s. \\
\hline Light supply $\left(\mu \mathrm{mol} \mathrm{s}{ }^{-1}\right)$ & $305.6 \pm 62.8$ & $297.9 \pm 60.6$ & $291.8 \pm 65.9$ & 4 & $\mathrm{~F}=0.049$, n.s. \\
\hline \multicolumn{6}{|l|}{ River Rhine } \\
\hline Flow velocity $\left(\mathrm{m} \mathrm{s}^{-1}\right)$ & $0.28 \pm 0.11$ & $0.30 \pm 0.15$ & $0.26 \pm 0.14$ & 8 & $\mathrm{~F}=0.016$, n.s. \\
\hline Oxygen content $\left(\mathrm{mg} \mathrm{L}^{-1}\right)$ & $10.16 \pm 0.70$ & $10.16 \pm 0.70$ & $10.17 \pm 0.70$ & 8 & $\mathrm{~F}=0.000$, n.s. \\
\hline Oxygen saturation $(\%)$ & $95.6 \pm 2.3$ & $95.5 \pm 2.2$ & $95.6 \pm 2.2$ & 8 & $\mathrm{~F}=0.003$, n.s. \\
\hline Ion conductivity $\left(\mu \mathrm{S} \mathrm{cm}^{-1}\right)$ & $454.4 \pm 15.2$ & $453.2 \pm 17.8$ & $453.1 \pm 17.4$ & 8 & $\mathrm{~F}=0.015$, n.s. \\
\hline $\mathrm{pH}$ value & $7.99 \pm 0.06$ & $8.0 \pm 0.05$ & $7.99 \pm 0.07$ & 7 & $\mathrm{~F}=0.078$, n.s. \\
\hline Temperature $\left({ }^{\circ} \mathrm{C}\right)$ & $12.5 \pm 2.1$ & $12.5 \pm 2.1$ & $12.5 \pm 2.1$ & 8 & $\mathrm{~F}=0.0000$, n.s. \\
\hline Light supply $\left(\mu \mathrm{mol} \mathrm{s}{ }^{-1}\right)$ & $85.4 \pm 44.0$ & $77.9 \pm 37.4$ & $70.3 \pm 31.6$ & 7 & $\mathrm{~F}=0.277$, n.s. \\
\hline
\end{tabular}

resulted in similar values at the end of the experiment. Accounting for this difficulty, we analysed the influences of the biomass gradient of $D$. villosus on the benthic community in the flumes measured at the sampling after 5 weeks. Only the adult individuals of D. villosus $(>8 \mathrm{~mm})$ in the baskets were used to explain the experimental results because we assumed adults to have the largest impact on other macroinvertebrates and because small $D$. villosus were not as successfully manipulated as larger and adult individuals at the start of the experiment. The similarity between the community compositions (excluding $D$. villosus adults) in the flumes was analysed with nMDS based on the Bray Curtis distance (data fourth root transformed), and afterwards the biomass gradient of the $D$. villosus adults in the experiment was fitted to the community data to test for its influence (function envfit, $\mathrm{R}$ package vegan, 999 permutations). The impact of the manipulated biomass of D. villosus adults at the start of the mesocom experiments (treatment 'low' and 'high') on single species biomasses after 5 weeks was tested with a one-sample $t$ test comparing the relative difference of a single population against the mean value of the 'control' treatment. The species-specific analyses were performed for the most common taxa in the mesocosm flumes occurring in at least two-thirds of the samples.

\section{Results}

Invasion history of $D$. villosus in the two rivers

D. villosus invaded the upper reaches of the River Elbe in 2001 and established high population densities very fast (Fig. 2; maximum: 336 individuals $\mathrm{m}^{-2}$ in 2001, 1880 individuals $\mathrm{m}^{-2}$ in 2002). While D. villosus was not observed in hand net samples in $2000(n=14$, operated by German Federal Institute of Hydrology), it was already found in $43 \%$ of the quantitative samples in 2001 and consistently reached high abundances in the following years (with occurrence of 43-95\% in the annual samples, Electronic Supplementary Material Table 1). Consequently, the long-term data set of the River Elbe was split into the two periods, 'before' and 'after' D. villosus invasion (1992-2000 and 2001-2013, respectively), for further analyses. In the River Rhine, D. villosus appeared first in 1995 
(maximum 16 individuals $\mathrm{m}^{-2}$ ) and was only occasionally found in low densities over the next 5 years (in 11-61\% of the annual samples, Electronic Supplementary Material Table 2). Thereafter, the species was found in most of the annual samples (in 63-100\%, Electronic Supplementary Material Table 2) and in high densities (Fig. 2). Because of the differences in invasion intensity, three consecutive time periods were identified and compared in the River Rhine, before invasion (1990-1994), during invasion (1995-1999) and after the establishment of D. villosus (2000-2013).

Long-term effects of D. villosus on the benthic communities

A significant change in the benthic community composition in the River Elbe that could clearly be related to the invasion of $D$. villosus was not observed. Although a high inter-annual variation of the total benthic density and the density of $D$. villosus was apparent in the long-term data of the River Elbe (Fig. 2), neither the mean benthic density nor the mean taxa number nor the Shannon diversity changed significantly between the phases before and after the invasion $(p>0.05, \mathrm{n}=18,1000$ permutations, Figs. 2, 3a, b). Likewise, the absolute number of native taxa (before: $13 \pm 3$, after: $10 \pm 4$, mean $\pm \mathrm{SD}$ ) and the density of native individuals (Fig. 3c) did not change significantly between the two periods ( $p>0.05, \mathrm{n}=18,1000$ permutations). Only the proportion of native taxa on total taxa number decreased in the phase after the invasion of $D$. villosus compared to that before the invasion (before: $93 \pm 1.4 \%, \quad$ after: $76 \pm 9 \%, \quad$ mean $\pm S D$, $p<0.001, \mathrm{n}=18,1000$ permutations).

The benthic species composition in the River Elbe showed significant differences between the years before and after the D. villosus invasion (function anosim, $\mathrm{R}=0.435, p<0.001, \mathrm{n}=421$ ). However, there seems to be a continuous shift in species composition over the whole observation period. Consequently, species composition might be more dependent on the specific year than on the invasion phase of D. villosus, as is indicated by the large distances between the annual values in the nMDS (Fig. 4a). The distance between the 1999 and 2001 samples (before vs. after invasion) is smaller than the distances between several other years. For the benthic community composition in samples after the invasion, sampling year and $D$. villosus density were identified as the two significant predictors (envfit analyses, Table 2). The first two axes of the db-RDA explained only a small proportion of the variability in the benthic
Fig. 2 Densities of $D$. villosus (left y-axes, boxwhisker-plots, outliers as circles) and total invertebrate density (right $y$ axes, grey lines and triangles, means and standard errors) in the Rivers Elbe (a) and Rhine (b; number of samples given at the top). First occurrence of D. villosus was in 2001 in Elbe and in 1995 in Rhine

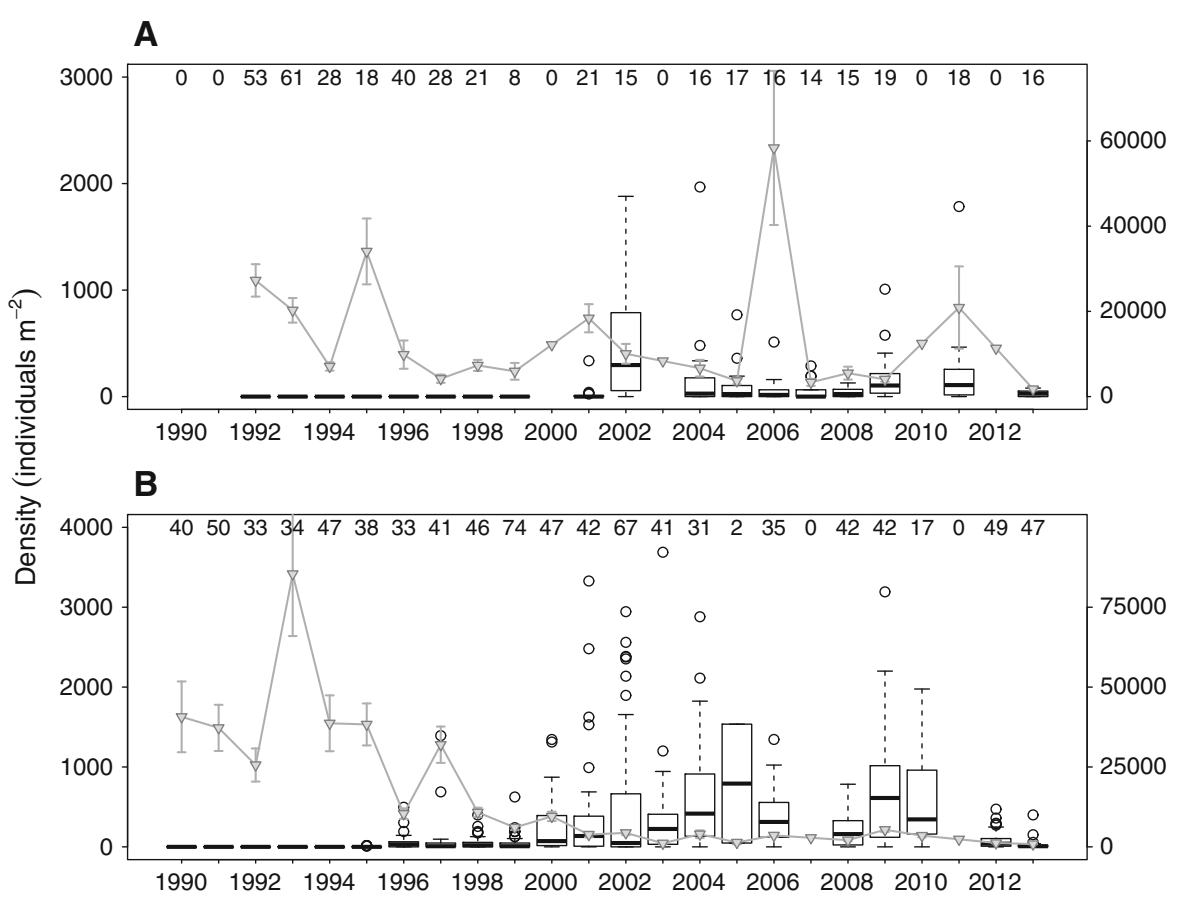



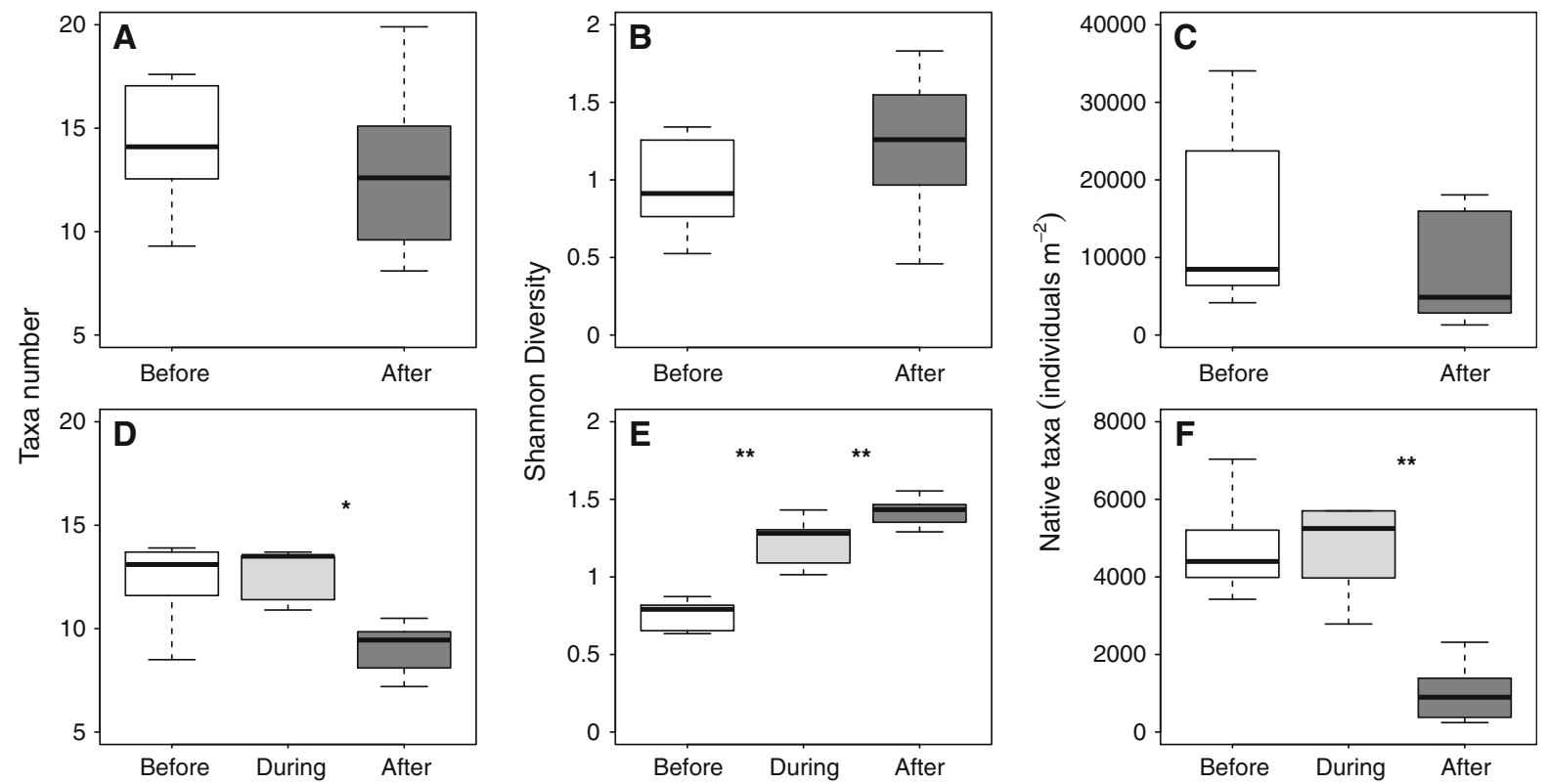

Fig. 3 Taxa number, Shannon Diversity index and density of native taxa (individuals $\mathrm{m}^{-2}$ ) in the Rivers Elbe $(\mathbf{a}-\mathbf{c})$ and Rhine (d-f) in the time before invasion (white), after establishment

(darkgrey) and during invasion phase (lightgrey, only Rhine) of D. villosus. Significant differences are marked with asterisks (* $p$ value $<0.05, * * p$ value $<0.001$ )

community (10.4\%, Fig. 5). The proportion of the sample variance explained by the predictor 'year' was $9.1 \%$, while the predictor ' $D$. villosus' explained only $1.3 \%$ of the variance (Table 3 ). The two predictors were directed orthogonally to each other in the plot, indicating independent effects. Densities of the majority of species were either not affected by changing $D$. villosus densities or tended to increase slightly (e.g. Erpobdella octoculata, Heptagenia sulphurea, Bryozoa). Only the caddisfly Hydropsyche spp. and oligochaetes tended to decrease with increasing $D$. villosus density (Fig. 5). The densities of most taxa seemed to depend much more on 'sampling year' because they decreased (e.g. Simulium spp., Chironomidae, Ancylus fluviatilis) or increased (e.g. Jaera sarsi, Corbicula spp., Dikerogammarus haemobaphes) in the direction of this predictor (Fig. 5).

In the River Rhine, in contrast, we observed several significant changes between the phase before and after D. villosus invasion. First, total benthic density showed a significant decrease from the phases before to that during the invasion $(p<0.05)$ and to the phase
Fig. 4 nMDS plots of mean community composition for every year in rivers Elbe (a) and Rhine (b). Each circle represent the mean community structure in 1 year, lines connect the years, subsequently. Marked are some years of the monitoring defined as tipping points of $D$. villosus invasion (bold) and the start and end of the long-term monitoring
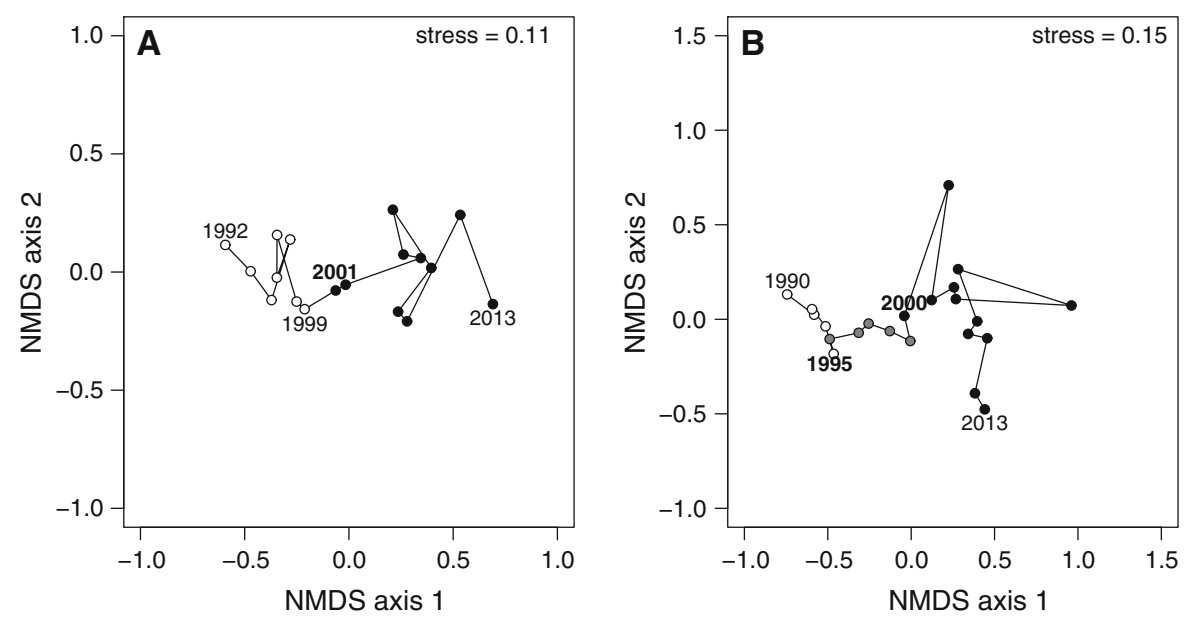
Table 2 Influence of environmental vectors on the benthic community based on envfit (999 permutations), which fit the variables onto nMDS ordination of community data

\begin{tabular}{lcccc}
\hline Predictor & NMDS axis 1 & NMDS axis 2 & $R^{2}$ & $P$ value \\
\hline Elbe_after invasion & & & & \\
$\quad$ Year & 0.662 & 0.749 & 0.515 & 0.001 \\
Sampling location & 0.151 & 0.989 & 0.003 & 0.82 \\
D. villosus density & -0.868 & 0.496 & 0.053 & 0.007 \\
Rhein-during invasion & & & & \\
Year & -0.457 & 0.889 & 0.483 & 0.001 \\
Sampling location & -0.956 & -0.295 & 0.014 & 0.26 \\
D. villosus density & 0.775 & 0.632 & 0.038 & 0.009 \\
Rhein-after establishment & & & & \\
Year & -0.916 & 0.402 & 0.354 & 0.001 \\
Sampling location & -0.414 & -0.910 & 0.051 & 0.001 \\
D. villosus density & 0.972 & 0.235 & 0.051 & 0.001 \\
\hline
\end{tabular}

Table 3 Results of the permutation test of db-RDA (999 permutations) with the proportions of each predictor explaining the sample variance

\begin{tabular}{lcll}
\hline Predictor & $F$ value & $P$ value & Proportion \\
\hline Elbe-after invasion & & & \\
$\quad$ Year & 15.9 & 0.001 & 0.091 \\
$\begin{array}{l}\text { D. villosus density } \\
\text { Rhine-during invasion }\end{array}$ & 2.3 & 0.005 & 0.013 \\
Year & 20.74 & 0.001 & 0.085 \\
D. villosus density & 3.18 & 0.002 & 0.013 \\
Rhine-after establishment & & \\
Year & 21.56 & 0.001 & 0.049 \\
Sampling location & 8.46 & 0.001 & 0.018 \\
D. villosus density & 4.71 & 0.001 & 0.01 \\
\hline
\end{tabular}

community-related indices were observed (Fig. 3). However, the Shannon diversity increased continuously from one phase to the next ('before' vs. 'during': $p<0.001$, 'during' vs. 'after': $p<0.05,1000$ permutations, $n=24$, Fig. 3e).

In the River Rhine, there were also significant changes in community composition between the three phases (function anosim, $p<0.001$ for all combinations) and the largest difference was observed between the years before the invasion and after the establishment of $D$. villosus ('before' vs. 'after': $\mathrm{R}=0.589$, 'before' vs. 'during': $\mathrm{R}=0.246$, 'during' vs. 'after': $\mathrm{R}=0.227$; function anosim). The nMDS plot of the annual samples showed large distances between the samples after the establishment whereas the distances 
in the years before and during invasion were relatively low, indicating high degrees of similarity (Fig. 4b). Like in the River Elbe, the influence of the predictors on the community composition was low. The first two axes of the db-RDA explained $9.8 \%$ of the variability in the benthic community during the invasion and only $7.3 \%$ after establishment (Fig. 6). Although the density of $D$. villosus was admittedly a significant predictor (envfit function, Table 2), it only explained 1.3 and $1 \%$ (during and after establishment, respectively) of the sample variances (Fig. 6; Table 3). By contrast, the predictor 'year' was also significant in both data sets (envfit function, Table 2) and orthogonally directed to the predictor ' $D$. villosus', explained a higher proportion of the variability (Fig. 6; Table 3). In the years after establishment, 'sampling location' was an additional predictor, explaining $1.8 \%$ of the sample variance and acting in the opposite direction to the predictor ' $D$. villosus'. During the invasion of $D$. villosus, most of the species showed either no changes in densities or a tendency to increase at sites with higher D. villosus density (e.g. Dreissena polymorpha, Psychomyia pusilla, Ancylus fluviatilis, Gammaridae; Fig. 6a), while the sampling year was more important for the density change of some other taxa (e.g. J. sarsi, Chelicorophium spp.). However, in the years after the invader's establishment, a lot of taxa responded to the temporal predictor ('year'). Very few taxa showed a slight decrease in densities parallel to the density

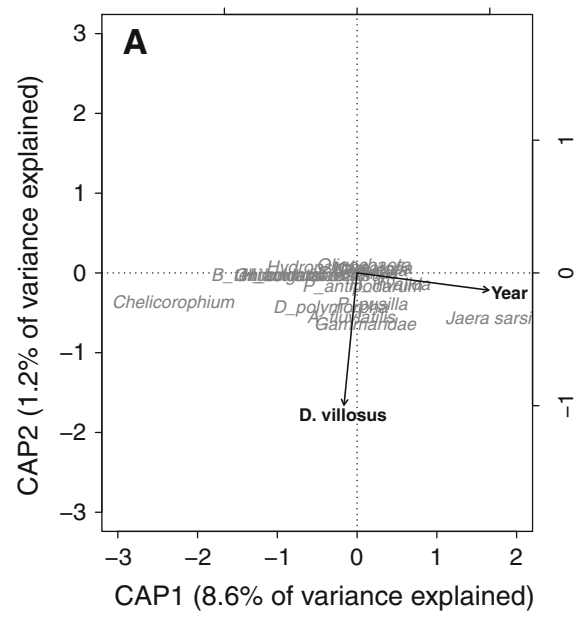

Fig. 6 Distance-based redundancy analysis (db-RDA) of the significant predictors (arrows), year, sampling location and $D$. villosus density, for the benthic community in River Rhine in the time periods during the invasion of D. villosus (a, 1995-1999, $\mathrm{n}=222)$ and after the etsablishment (b, 2000-2013, $\mathrm{n}=413)$. gradient of D. villosus (e.g. Oligochaeta, Gammaridae; Fig. 6b).

Additionally, in the long-term data set, the speciesspecific analyses of the densities of $D$. villosus and the most important native and invasive taxa in the river communities showed mainly positive correlations in both rivers or were not correlated to $D$. villosus density (Table 4). The only exception was observed in the River Rhine after $D$. villosus establishment, where three out of eight native taxa were negatively affected (Gammaridae, H. contubernalis, Oligochaeta), and only two taxa were positively correlated. Generally, positive correlations among all of the taxa dominated in both rivers (Electronic Supplementary Material Fig. 1-3).

Community effects of $D$. villous in the mesocosm experiments

In both mesocosm experiments, we observed no significant impact of the invader $D$. villosus on the community composition along the biomass gradient in the flumes (Elbe: $\mathrm{r}^{2}=0.024, p=0.94$; Rhine: $\mathrm{r}^{2}=0.056, p=0.85$; function envfit, Fig. 7). The species-specific impact of the D. villosus biomass seemed to be weak because there were only few significant changes in species biomasses between the treatments and none of the native taxa were affected (Fig. 8). At the end of the Elbe mesocosm experiment,

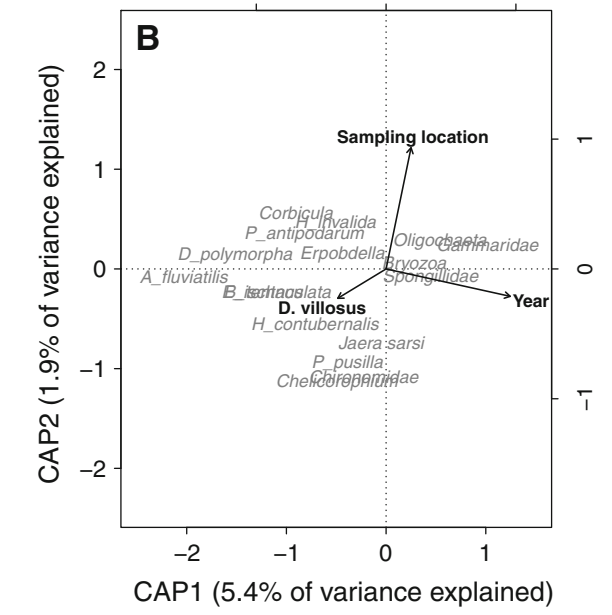

Only the first two axes are shown; only taxa with occurrence in at least $10 \%$ (after) and $20 \%$ (during) of the samples and no sites displayed for clarity of the plot. Ordination of samples based on fourth root transformed species abundances and Bray Curtis similarities 
Table 4 Results of Kendall's rank correlations between the densities of D. villosus and these taxa, which were selected by indval function indicated as most relevant in the river communities in the different invasion phases (invasive taxa $=$ inv, natives $=$ nat)

\begin{tabular}{|c|c|c|c|c|}
\hline Taxa & Abbr. & Elbe & Rhine 'during' & Rhine 'after' \\
\hline Ancylus fluviatilis (nat) & Anc & $0.14 *$ & $0.25 * * *$ & $0.35 * * *$ \\
\hline Asellus aquaticus (nat) & Asell & n.s. & - & - \\
\hline Bithynia tentaculata (nat) & Bith & - & n.s. & $0.12 * *$ \\
\hline Chelicorophium curvispinum (inv) & Cheli & - & $0.14 * *$ & $0.09 * *$ \\
\hline Chironomidae (nat) & Chiro & - & n.s. & n.s. \\
\hline Corbicula fluminea/fluminalis (inv) & Corb & $0.19 * *$ & - & - \\
\hline Dikerogammarus haemobaphes (inv) & Dhaem & n.s. & - & - \\
\hline Dreissena polymorpha (inv) & Dreiss & - & $0.22 * * *$ & $0.18 * * *$ \\
\hline Dugesia lugubris/polychroa (nat) & Dlug & n.s. & - & - \\
\hline Dugesia tigrina (inv) & Dtigr & - & n.s. & n.s. \\
\hline Echinogammarus ischnus (inv) & Echin & - & $0.17 * *$ & $0.11 * *$ \\
\hline Erpobdella octoculata (nat) & Erpob & $0.24 * * *$ & - & - \\
\hline Gammaridae & Gamm & - & $0.49 * * *$ & $-0.13 * * *$ \\
\hline Gammarus tigrinus (inv) & Gtigr & - & n.s. & n.s. \\
\hline Heptagenia sulphurea (nat) & Hepta & $0.24 * * *$ & - & - \\
\hline Hydropsyche contubernalis (nat) & Hcont & $0.12 *$ & $0.12 *$ & $-0.1 *$ \\
\hline Hydropsyche spp. (total) (nat) & Hydro & n.s. & $0.13 *$ & n.s. \\
\hline Jaera sarsi (inv) & Jaera & $0.31 * * *$ & $0.3 * * *$ & $0.28 * * *$ \\
\hline Oligochaeta (nat) & Oligo & n.s. & n.s. & $-0.08 *$ \\
\hline Pisidium spp. (nat) & Pis & - & n.s. & n.s. \\
\hline Psychomyia pusilla (nat) & Psych & $0.14 *$ & - & - \\
\hline
\end{tabular}

Only samples since the invasion of D. villosus were used (River Elbe: years up from 2001, River Rhine 'during' invasion: years 1995-1999, River Rhine 'after' establishment: years up from 2000). Given are only these correlation coefficients, which showed significant relationships (- not analysed, n.s. = non-significant, ${ }^{*} p$ value $<0.05$, ** $p$ value $<0.01$, *** $p$ value $<0.001$ ), negative correlations were bold typed. For all species-specific interactions see Supplement using the abbreviations

the biomass of adult $D$. villosus was still significantly lower in the treatment 'low'than in the 'control' (onesample $t$ test, $p=0.047, \mathrm{n}=3$ ), whereas the biomass in the treatment 'high'did not differ from the 'control'. Neither the total potential prey biomass (excluding $D$. villosus adults) nor any of the considered single taxa was affected by the manipulated $D$. villosus biomasses, because none of these taxa showed any significant biomass changes relative to the control after 5 weeks (one-sample $t$ test, $p>0.05, \mathrm{n}=3$, Fig. 8). At the end of the Rhine mesocosm experiment, the biomasses of adult D. villosus did not differ significantly between the treatments (one-sample $t$ test, $p>0.05, \mathrm{n}=3$, Fig. 8). Nevertheless, the biomasses of Chelicorophium spp. and E. ischnus were reduced in the 'low' treatment (one-sample $t$ test, $\mathrm{n}=3, p=0.017$ and $p=0.052$, respectively) and
$J$. sarsi biomasses tended to decrease in the 'low' treatment and to increase in the 'high' treatment (onesample $t$ test, $\mathrm{n}=3, p=0.082$ and $p=0.069$, respectively). The biomass of the total potential prey also showed a tendency to decrease at a low $D$. villosus biomass (one-sample $t$ test, $p=0.065, \mathrm{n}=3$, Fig. 8).

\section{Discussion}

Long-term effects of $D$. villosus on community composition

The invasion of non-native species in European rivers is assumed to represent a threat to the aquatic biodiversity and ecological functioning of river ecosystems (Sala et al. 2000; Devin et al. 2005; 
Fig. 7 nMDS plot of community composition in the mesocosms experiments in the rivers Elbe (a) and Rhine (b). The increasing biomass gradient of $D$. villosus adults (mg dry weight per basket) in the flumes is shown with increasing bubble size. The gradient is not a significant explainable vector for data variability. Ordination of samples based on fourth root transformed biomasses of species and Bray Curtis similarities
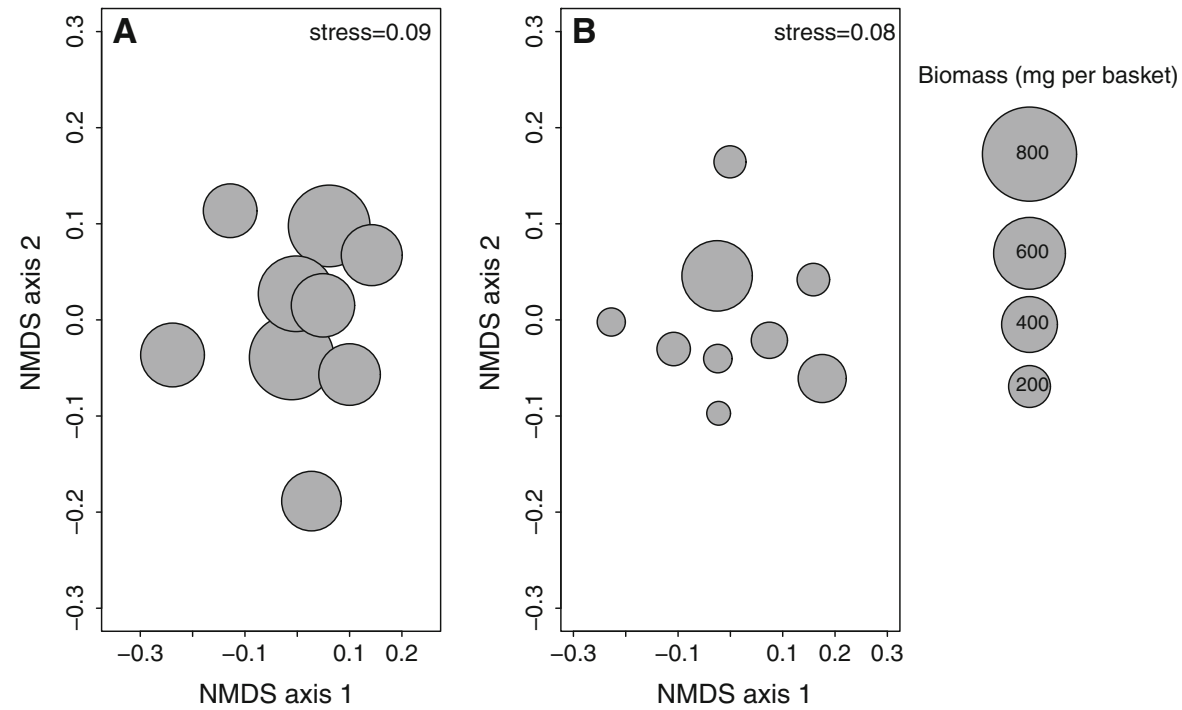

A

D. villosus (ad)
D. villosus (juv)
Potential prey
Chelicorophium
Corbicula
D. haemobaphes
Jaera sarsi
H. contubernalis
C. lepida

C. lepida

A. fluviatilis

H. sulphurea

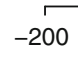<smiles>[Li][Mg][Mg]</smiles><smiles>[Li]</smiles>

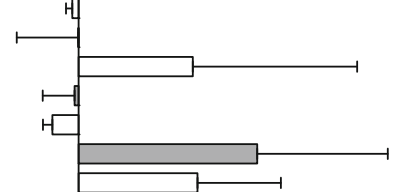

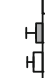

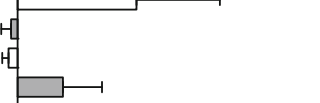

B

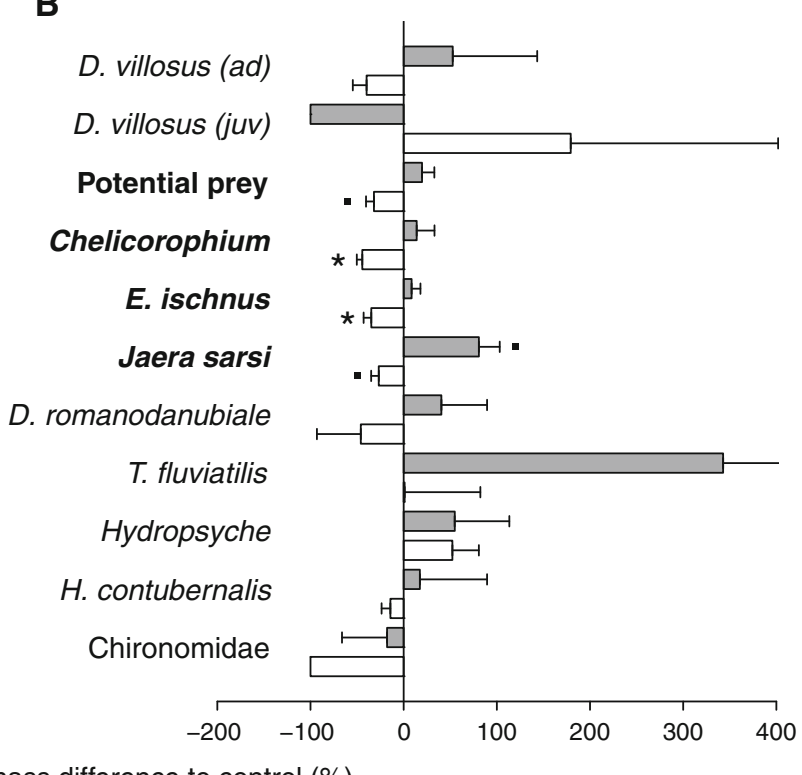

Percentage biomass difference to control (\%)

Fig. 8 Percentage differences (\%) of species biomasses (means $+1 \mathrm{SE}, \mathrm{n}=3$ ) in the manipulated flumes with low (white bars) and high biomasses (grey bars) of D. villosus related to control flumes in rivers Elbe (a) and Rhine (b). For full scientific names see Table 4 (additionally Cheumatopsyche lepida, Dendrocoelum romanodanubiale, Theodoxus fluviatilis,

Didham et al. 2005; Ricciardi and MacIsaac 2011; Katsanevakis et al. 2014). In the present study, we failed to observe strong negative effects of $D$. villosus on the benthic macroinvertebrates in the rivers Elbe and Rhine. The lack of such effects was rather
Chelicorophium includes C. curvispinum and C. robustum, $\mathrm{ad}=$ adults, juv $=$ juveniles). Taxa showing significant differences in manipulated flumes to control are bold typed (onesample $t$ test, $-p<0.1, * p<0.05$ ). Because of high variance in T. fluviatilis biomass, the standard error $(+414.6 \%)$ is not completely drawn

surprising because many authors suspect a strong and rapid impact of this highly successful invader on the community (Dick and Platvoet 2000; Boets et al. 2010; Piscart et al. 2010). Two long-term studies in Belgium rivers indicated that D. villosus influenced 
the resident macroinvertebrate assemblage that appeared mainly in a reduced frequency of the native taxa (Boets et al. 2011; MacNeil et al. 2013). Nevertheless, the specific relevance of $D$. villosus for community changes is often not clear and depends on habitat conditions (e.g. substratum, chemical water quality) or the occurrence of other invaders, and should be therefore regarded in a wider invasion scenario including several other co-invaders (MacNeil et al. 2013). Another extensive study in the Ijsselmeer area (The Netherlands) failed to observe severe negative impacts of $D$. villosus invasion, although the authors presume that the improvement of the water quality over a longer time period could have mitigated the negative impacts of invasion (Noordhuis et al. 2009). However, a lot of the studies that reveal a general negative impact of $D$. villosus are based on comparisons of single years close to or after the invasion event (Bollache et al. 2004; Devin et al. 2005; Bernauer and Jansen 2006; van Riel et al. 2006). Especially in river ecosystems, there is a great annual variability in species densities, which might lead to an overestimation or a masking of effects by $D$. villosus when only single years are compared. In addition, the reports of strong effects are mainly based on the observation that $D$. villosus displaces other amphipods or native macroinvertebrates (Bernauer and Jansen 2006; Kinzler et al. 2009; Noordhuis et al. 2009; Piscart et al. 2010). In the benthic community of the River Elbe, amphipods were already rare before the invasion of $D$. villosus $(0.06 \%$ of the total density, $\mathrm{n}=279$, 1992-2000), which might be one possible explanation of the lack of negative direct effects. On the other hand, in the River Rhine, the mean proportion of amphipods accounted for nearly one-third of the total macroinvertebrate density $(27.8 \%, \mathrm{n}=395$, 1990-1994), and the amphipod species showed positive or no correlations to D. villosus density. Further, the appearance of other invasive species some years before, especially in the River Rhine (e.g. E. ischnus) could have already contributed to significant changes of the benthic community.

Although this study has not revealed very strong negative consequences of invasion, other negative impacts cannot be excluded. There might be indirect or sub-lethal effects on the community which induce slow changes of community composition. Such effects are difficult to identify and can be expected to be equally important for the ecosystem as fast and direct effects. The slow change of community structure observed in the monitoring data since the invasion of D. villosus might be an evidence for such indirect effects. Although an experimental approach was included into our study to differentiate between $D$. villosus effects and stochastic variability, we were not able to detect such slow changes with our experimental set-up due to the short duration and simplified habitat conditions in the mesocosm experiments. In addition, the majority of the vulnerable native species might already have declined or even disappeared from the river at the time of our experiments because the invasion occurred at least 10 years ago. Consequently, any impact on these species could not be assessed in our mesocosm experiments. Even though this is a likely scenario, we assume that we would still have been able to detect strong negative interactions with the remaining species. The mesocosm experiments covered a large biomass gradient of $D$. villosus and therefore strong direct interactions like predation or competition should have resulted in negative correlations at least in the River Elbe, where still a relatively high proportion of native taxa was present. The seemingly positive responses of the three invasive crustaceans to $D$. villosus are more difficult to interpret because we can hardly distinguish a positive response from the slight positive effect of the manipulation on crustacean biomasses at the start of the experiment. Nevertheless, we are reasonable sure that $D$. villosus is not a key predictor of the community composition and has no strong negative impacts on benthic macroinvertebrates. If it would have had such strong effects on the benthic community at the studied sites, they would have been detected either in the mesocosm experiment over the biomass gradient or in the monitoring data during the first years of invasion in both rivers.

The results indicate that the invasion process itself and the effects on the macroinvertebrate community can be river-specific and might depend on the initial species composition. In spite of the very fast colonisation of the studied region in the River Elbe in 2001, the monitoring data indicated only weak relationships between $D$. villosus densities and benthic community structure. Although we observed a temporal shift of the benthic community composition, this shift was rather slow and did not show an obvious difference in the community composition around the time of the invasion or along the density gradient of $D$. villosus after the invasion. Therefore, we conclude from our 
results that the invasive amphipod did not have strong direct negative effects on the benthic community structure at the study site. Quite the opposite, speciesspecific analyses indicated exclusively positive correlations of $D$. villosus density with native and invasive species in the River Elbe. We assume the same for the River Rhine during the invasion phase of $D$. villosus (1995-1999), where only slight changes in the community composition were found and some species showed positive correlations. In contrast, after the establishment of D. villosus, when its density increased massively in the River Rhine, we observed a clear response of the benthic community. This was reflected by changes of community-related indices like total density, taxa number and the proportion of native species, which were negatively affected in the second phase of the invasion. It was also indicated by the increased inter-annual variability in the community composition after the establishment compared to the phases before and during the invasion. These differences between the two rivers might have been caused by differences in the initial community composition. It has to be considered that the community in the Upper Elbe was strongly dominated by native species prior to the appearance of $D$. villosus (proportion of native taxa in total taxa number: 90-95\%), whereas the River Rhine was already populated by a higher proportion of invasive species when $D$. villosus appeared (proportion in total taxa: 20-40\%). In addition, D. villosus was one of the first invaders in the Upper Elbe that reached high densities (ARGEElbe 2002), whereas other invasive species were not a significant component, and especially other amphipods were largely absent (Grabow et al. 1998; Schöll and Balzer 1998; Tittizer et al. 2000; Electronic Supplementary Material Table 1). In contrast to this, the River Rhine had already been inhabited by other highly successful invaders prior to the first appearance of $D$. villosus, particularly by amphipod species that had reached high abundances (e.g. Chelicorophium spp., E. ischnus) (Schöll 1990a, b; Kley and Maier 2006; Electronic Supplementary Material Table 2). Because other amphipods are often regarded as main competitors of D. villosus, the obvious lack of serious competitors in the River Elbe could also be an important reason for the fast establishment of high population densities there, while their presence might have slowed down the invasion process in the River Rhine.
Contrary to our expectation, the often voiced assumptions that $D$. villosus reduces species diversity cannot be supported by our data. In our study, $D$. villosus apparently increased the Shannon diversity. However, this could probably be interpreted as a consequence of a more homogenous distribution of the taxa rather than as a positive effect on species diversity. An increase of species richness seems to be possible as well, especially in highly degraded systems such as canals, where a revaluation of the biological water quality is promoted by an increase of the initial low species diversity and taxa number with the appearance of invasive species (Boets et al. 2011). The observation that the number and density of native species decreased in the River Rhine can have direct consequences for the practice in water management and assessment. The ecological quality of water bodies is often assessed by using reference based tools such as macroinvertebrate-derived biotic indices (MacNeil et al. 2013; MacNeil 2014; Schöll et al. 2015), therefore a decline of the number of native species due to the occurrence of invasive species can lead to an apparent reduction of the ecological status.

Species-specific effects of $D$. villosus on native and invasive taxa

The previously assumed strong negative interactions with the native taxa were not generally observed in this study. The native taxa Oligochaeta and Hydropsyche contubernalis were the only ones showing a significant density decrease with increasing $D$. villosus densities, which parallels a temporal coincidence of the same relationship for $H$. contubernalis and Oligochaeta in the River Rhine since the year 2000 (Schöll et al. 2015). These correlations that we observed in this later invasion phase could indicate a real interaction with $D$. villosus and a negative impact of the invader because they did not appear in other species-specific comparisons in our study. Because predation on native macroinvertebrates does not play an important role in the Rivers Elbe and Rhine (Hellmann et al. 2015), competition for food or habitat might be a probable reason for the observed effects on native taxa. Supporting this assumption, hydropsychid larvae showed a similar isotope niche to D. villosus in these rivers (Hellmann et al. 2015). However, as both decreasing native taxa were relatively abundant before and after the invasion (Electronic Supplementary 
Material Table 3), the negative impact should not be over-emphasised. The negative correlation of $D$. villosus with Gammaridae, which includes all present amphipod species in the years after establishment in the River Rhine, also appears very weak due to the methodological limitation of the sample processing (low taxonomic resolution of this group). The correlations with well-identified amphipod species seemed to be more meaningful and did not show the same results like the correlation with the whole taxonomic group Gammaridae.

In general, our results seem to support the 'invasional meltdown' theory. We observed not only a general dominance of positive correlations between all included taxa, there were also much more positive ones than negative ones between the densities of $D$. villosus density and non-native species in both rivers. Additionally, in River Rhine, the community-level effects of the invader seemed to be more intense than in the River Elbe. Therefore, it stands to reason that previously established invasive species might have facilitated the $D$. villosus invasion and accelerated or intensified the invader's impact on the native and invasive species (Simberloff and Von Holle 1999). However, there are also contradicting facts. The invasion process in the River Rhine was slower than in the River Elbe, which is not consistent with the supposed facilitation by previously established invaders. In addition, positive correlations between species densities do not necessarily prove a positive species interaction but could also be caused by similar environmental requirements of two species and thus represent pseudo-correlations. In fact, the dominance of positive correlations of other amphipod densities with $D$. villosus was very surprising and largely contradicts the results of previous studies. From our data it cannot be discerned whether the correlations indicate a true positive species interaction or are caused by similar requirements to habitat quality or resource availability (Kley and Maier 2005; Maazouzi et al. 2009; Platvoet et al. 2009; Boets et al. 2014; Kobak et al. 2015). Although the samples were taken over a stretch of $60-100 \mathrm{~km}$ and a wide range of substratum grain sizes, it cannot be excluded that potential negative interactions between $D$. villosus and native or non-native species were mitigated or facilitated by environmental gradients along the sampled habitats. MacNeil et al. (2013) have shown that the type of substratum can promote the effects of $D$. villosus on other species with the lowest negative impact on sandy substrata. Further, the flow regime in used habitats could affect the interactions between $D$. villosus and its prey (Felten et al. 2008). Differences in inter-specific competition or intraguild predation, e.g. between amphipod species, could also be a result of the environmental gradients along the different habitats (MacNeil and Dick 2012). In this sense it is conceivable that both predation and an intense interspecific competition between $D$. villosus and other amphipods would at least lead to a compensation of the positive habitat effects.

Environmental factors as possible driver for community changes

Another more probable reason for the change of benthic community structure throughout the investigated years could be a trend in environmental factors (such as water temperature and water quality characteristics) or stochastic events (such as floods or droughts) because environmental factors are known to determine the structure of the benthic community to a considerable extent (Statzner et al. 1988; Buffagni et al. 2009). This expectation was supported by the observation that the predictor 'year', which can be assumed to represent the inter-annual variability of environmental factors, explained a larger part of the variability in the community composition than the predictor ' $D$. villosus density'. However, the low percentage of explained variability of the data by all tested predictors together (at most about 10\%) indicated that there are one or more other environmental gradients with a high explanatory power which were not analysed. Such factors on a meso- or microhabitat scale could be substrate diversity or grain sizes, food availability, hydro-morphological or physico-chemical habitat conditions. As in other observational studies, it seems almost impossible to distinguish the effects of all these environmental factors from invasion effects (Noordhuis et al. 2009). The improvement of water quality by reduction of organic pollution and salinity in European rivers during the last decades (Tittizer et al. 1994; Schöll and Fuksa 2000; Boets et al. 2011) might also be a reason for the different responses of the studied river systems to invasion and might have masked the effects of $D$. villosus. In the River Elbe, the slow shift in community composition is likely to represent the response of the 
community to a long-term trend of increasing water quality since 1990 (Schöll and Fuksa 2000) and not primarily a response to the invasion of $D$. villosus. This is supported by the fact that a similar slow community change was observed before the invasion. Although replacement of pollution-tolerant species by more oxygen-sensitive taxa and a significant increase in species number started in the mid-90s, it was still going when D. villosus invaded the River Elbe (Schöll and Fuksa 2000) and was even discernible in the period after that. In the River Rhine, the recovery of the community from pollution was observed much earlier (from 1970; Tittizer et al. 1994) and appeared to be completed in the 1990s (IKSR-Internationale Kommission zum Schutz des Rheins 2015). This different timing of the community recovery might at least partly explain the difference in community effects between the two rivers. The improvement of the water quality in highly degraded rivers can increase the taxa number by the immigration of both native and invasive species (Boets et al. 2011), and thereby effectively mask the community response to invasion. Because recovery was still going on in the River Elbe, community effects might be weaker, whereas in the River Rhine a stronger decline of species number and benthic densities could be observed due to largely completed recovery. Nevertheless, the long-term field observations were supported by the results of the mesocosm experiments, according to which differing $D$. villosus biomasses did not explain the structure of the benthic community. However, it is possible that migration to and from the mesocosms might have masked strong effects of $D$. villosus. The channels were relatively small $(4.80 \mathrm{~m}$ long), and during the experiments the density differences of the initial manipulation could be at least partly compensated by population dynamics (e.g. growth and reproduction of $D$. villosus) or the drift activity of $D$. villosus. In the River Rhine, organismic drift into and out of the flumes was quantified during a similar mesocosm experiment in spring and indicated a net loss of individuals in the mesocosms at high densities and a net accumulation at low densities (unpublished data). However, the drift activity of $D$. villosus is reported to be higher in spring and summer than in autumn and winter in upper reaches of the River Rhine (van Riel et al. 2011). Because our experiments were performed in late autumn and the drift was observed to be low for other macroinvertebrates in our experiments (unpublished data), we suppose that a compensation of $D$. villosus effects is rather unlikely. Moreover, the observed similar trends in the long-term study and the experiment in both rivers support our interpretation.

\section{Conclusion}

We conclude from our data that strong negative effects on benthic macroinvertebrates caused by the successful invader $D$. villosus are no general pattern in European river communities. If $D$. villosus does affect other species, positive species interactions (real and apparent ones) seem to be at least similarly likely as negative interactions. We therefore support Katsanevakis et al. (2014) statement that the positive impact of invaders might be often underestimated in several ecosystems and therefore should perhaps be the focus of further investigations. We suppose that if the spatial and temporal variability of environmental conditions has a stronger impact on the native community than $D$. villosus, the relevance of the invader for structuring benthic communities is lower than previously assumed and should even be considered in the wider context of co-invasion of several taxa.

Acknowledgments We would like to thank our cooperation partner in the project, the German Federal Institute of Hydrology, for helping with the organization of the mesocosm experiments. The German Waterways and Shipping Administration was a great help with field sampling and supported the experiments by providing ships and man-power. Our thanks are due to Amanda Habbershaw for linguistic support and the anonymous reviewers for helping to improve the manuscript. Financial support was provided by the German Research Foundation within an Emmy Noether grant (WI 3592/1).

Open Access This article is distributed under the terms of the Creative Commons Attribution 4.0 International License (http:// creativecommons.org/licenses/by/4.0/), which permits unrestricted use, distribution, and reproduction in any medium, provided you give appropriate credit to the original author(s) and the source, provide a link to the Creative Commons license, and indicate if changes were made.

\section{References}

Anderson MJ (2001) A new method of non-parametric multivariate analysis of variance. Austral Ecol 26:32-46 
ARGE Elbe - Arbeitsgemeinschaft für die Reinhaltung der Elbe (ed) (2002) Biomonitoring der Amphipodenfauna in der Oberen, Mittleren und Unteren Elbe, erste Ergebnisse aus 2001, Bearbeitung H.-J. Krieg. ARGE Elbe, Hamburg, pp 13

Bacela-Spychalska K, van der Velde G (2013) There is more than one 'killer shrimp': trophic positions and predatory abilities of invasive amphipods of Ponto-Caspian origin. Freshw Biol 58:730-741

Baumgärtner D, Rothhaupt K-O (2003) Predictive length-dry mass regressions for freshwater invertebrates in a prealpine lake littoral. Int Rev Hydrobiol 88:453-463

Benke AC, Huryn AD, Smock LA, Wallace JB (1999) Lengthmass relationships for freshwater macroinvertebrates in North America with particular reference to the southeastern United States. J N Am Benthol Soc 18:308-343

Bernauer D, Jansen W (2006) Recent invasions of alien macroinvertebrates and loss of native species in the upper Rhine River, Germany. Aquat Invasions 1:55-71

bij de Vaate A, Jazdzewski K, Ketelaars HAM, Gollasch S, van der Velde G (2002) Geographical patterns in range extension of Ponto-Caspian macroinvertebrate species in Europe. Can J Fish Aquat Sci 59:1159-1174

Boets P, Lock K, Messiaen M, Goethals PLM (2010) Combining data-driven methods and lab studies to analyse the ecology of Dikerogammarus villosus. Ecol Inform 5:133-139

Boets P, Lock K, Goethals PLM (2011) Using long-term monitoring to investigate the changes in species composition in the harbour of Ghent (Belgium). Hydrobiologia 663:155-166

Boets P, Pauwels IS, Lock K, Goethals PLM (2014) Using an integrated modelling approach for risk assessment of the 'killer shrimp' Dikerogammarus villosus. River Res Appl 30:403-412

Bollache L, Devin S, Wattier R, Chovet M, Beisel J-N, Moreteau J-C, Rigaud T (2004) Rapid range extension of the PontoCaspian amphipod Dikerogammarus villosus in France: potential consequences. Arch Hydrobiol 160:57-66

Brauns M, Gücker B, Wagner C, Garcia X-F, Walz N, Pusch MT (2011) Human lakeshore development alters the structure and trophic basis of littoral food webs. J Appl Ecol 48:916-925

Buffagni A, Casalegno C, Erba S (2009) Hydromorphology and land use at different spatial scales: expectations in a changing climate scenario for medium-sized rivers of the Western Italian Alps. Fundam Appl Limnol 174:7-25

Buric M, Koci L, Petrusek A, Kouba A, Kozak P (2009) Invaders eating invaders: potential trophic interactions between the amphipod Dikerogammarus villosus and juvenile crayfish Orconectes limosus. Knowl Manag Aquat Ecosyst 394-395. doi:10.1051/kmae $/ 2009015$

Carpenter SR (1996) Microcosm experiments have limited relevance for community and ecosystem ecology. Ecology 77(3):677-680

Devin S, Piscart C, Beisel J-N, Moreteau JC (2003) Ecological traits of the amphipod invader Dikerogammarus villosus on a mesohabitat scale. Arch Hydrobiol 158:43-56

Devin S, Beisel J-N, Usseglio-Polatera P, Moreteau JC (2005) Changes in functional biodiversity in an invaded freshwater ecosystem: the Moselle River. Hydrobiologia 542:113-120
Dick JTA, Platvoet D (2000) Invading predatory crustacean Dikerogammarus villosus eliminates both native and exotic species. Proc R Soc Lond B Biol Sci 267:977-983

Dick JTA, Platvoet D, Kelly DW (2002) Predatory impact of the freshwater invader Dikerogammarus villosus (Crustacea: Amphipoda). Can J Fish Aquat Sci 59:1078-1084

Didham RK, Tylianakis JM, Hutchison MA, Ewers RM, Gemmell NJ (2005) Are invasive species the drivers of ecological change? Trends Ecol Evol 20:470-474

Dufrêne M, Legendre P (1997) Species assemblages and indicator species: the need for a flexible ans asymmetrical approach. Ecol Monogr 67:345-366

Englund G, Cooper SD (2003) Scale effects and extrapolation in ecological experiments. Adv Ecol Res 33:161-213

Felten V, Dolédec S, Statzner B (2008) Coexistence of an invasive and a native gammarid across an experimental flow gradient: flow-refuge use, -mortality, and leaf-litter decay. Fundam Appl Limnol 172:37-48

Gallardo B, Aldridge DC (2013) The 'dirty dozen': socio-economic factors amplify the invasion potential of 12 high-risk aquatic invasive species in Great Britain and Ireland. J Appl Ecol 50:757-766

Grabow K, Eggers TO, Martens A (1998) Dikerogammarus villosus Sowinsky (Crustacea: Amphipoda) in norddeutschen Kanälen und Flüssen. Lauterbornia 33:103-107

Hellmann C, Wissel B, Winkelmann C (2013) Omnivores as seasonally important predators in a stream food web. Freshw Sci 32:548-562

Hellmann C, Worischka S, Mehler E, Becker J, Gergs R, Winkelmann C (2015) The trophic function of Dikerogammarus villosus (Sowinsky, 1894) in invaded rivers: a case study in the Elbe and Rhine. Aquat Invasions 10:385-397

IKSR - Internationale Kommission zum Schutz des Rheins (ed) (2015) Das Makrozoobenthos des Rheins 2012, federführende Bearbeitung F. Schöll. IKSR-Bericht 227d, Koblenz, pp 55

Josens G, bij de Vaate A, Usseglio-Polatera P, Cammaerts R, Chérot F, Grisez F, Verboonen P, Vanden Bossche J-P (2005) Native and exotic Amphipoda and other Peracarida in the River Meuse: new assemblages emerge from a fast changing fauna. Hydrobiologia 542:203-220

Katsanevakis S, Wallentinus I, Zenetos A, Leppäkoski E, Çinar ME, Oztürk B, Grabowski M, Golani D, Cardoso AC (2014) Impacts of invasive alien marine species on ecosystem services and biodiversity: a pan-European review. Aquat Invasions 9:391-423

Kinzler W, Kley A, Mayer G, Waloszek D, Maier G (2009) Mutual predation between and cannibalism within several freshwater gammarids: Dikerogammarus villosus versus one native and three invasives. Aquat Ecol 43:457-464

Kley A, Maier G (2005) An example of niche partitioning between Dikerogammarus villosus and other invasive and native gammarids: a field study. J Limnol 64:85-88

Kley A, Maier G (2006) Reproductive characteristics of invasive gammarids in the Rhine-Main-Danube catchment, South Germany. Limnologica 36:79-90

Kobak J, Jermacz L, Dzierzynska-Białonczyk A (2015) Substratum preferences of the invasive killer shrimp Dikerogammarus villosus. J Zool 297:66-76 
Koester M, Gergs R (2014) No evidence for intraguild predation of Dikerogammarus villosus (Sowinsky, 1894) at an invasion front in the Untere Lorze, Switzerland. Aquat Invasions 9:489-497

Koester M, Bayer B, Gergs R (2016) Is Dikerogammarus villosus (Crustacea, Gammaridae) a 'killer shrimp' in the River Rhine system? Hydrobiologia 768:299-313

Legendre P, Anderson MJ (1999) Distance-based redundancy analysis: testing multispecies responses in multifactorial ecological experiments. Ecol Monogr 69:1-24

Leuven RSEW, van der Velde G, Baijens I, Snijders J, van der Zwart C, Lenders HJR, bij de Vaate A (2009) The river Rhine: a global highway for dispersal of aquatic invasive species. Biol Invasions 11:1989-2008

Maazouzi C, Piscart C, Pihan J-C, Masson G (2009) Effect of habitat-related resources on fatty acid composition and body weight of the invasive Dikerogammarus villosus in an artificial reservoir. Fundam Appl Limnol 175:327-338

MacNeil C (2014) “The pump don't work, 'Cause the vandals took the handles"; why invasive amphipods threaten accurate freshwater biological water quality monitoring. Manag Biol Invasions 5: (in press)

MacNeil C, Dick JTA (2012) Intraguild predation may reinforce a species-environment gradient. Acta Oecol 41:90-94

MacNeil C, Boets P, Platvoet D (2012) 'Killer shrimps', dangerous experiments and misguided introductions: how freshwater shrimp (Crustacea: Amphipoda) invasions threaten biological water quality monitoring in the British Isles. Freshw Rev 5:21-35

MacNeil C, Boets P, Lock K, Goethals PLM (2013) Potential effects of the invasive 'killer shrimp' (Dikerogammarus villosus) on macroinvertebrate assemblages and biomonitoring indices. Freshw Biol 58:171-182

Meyer EI (1989) The relationship between body length parameters and dry mass in running water invertebrates. Arch Hydrobiol 117:191-203

Noordhuis R, Jv Schie, Jaarsma N (2009) Colonization patterns and impacts of the invasive amphipods Chelicorophium curvispinum and Dikerogammarus villosus in the Ijsselmeer area, The Netherlands. Biol Invasions 11:2067-2084

Oksanen J (2013). Multivariate analysis of ecological communities in R: vegan tutorial, http://cc.oulu.fi/ jarioksa/ opetus/metodi/vegantutor.pdf

Piscart C, Bergerot B, Laffaille P, Marmonier P (2010) Are amphipod invaders a threat to regional biodiversity? Biol Invasions 12:853-863

Platvoet D, Dick JTA, MacNeil C, van Riel MC, van der Velde $\mathrm{G}$ (2009) Invader-invader interactions in relation to environmental heterogeneity leads to zonation of two invasive amphipods, Dikerogammarus villosus (Sowinsky) and Gammarus tigrinus Sexton: amphipod pilot species project (AMPIS) report 6. Biol Invasions 11:2085-2093

R Development Core Team (2014) A language and environment for statistical computing. R Foundation for Statistical Computing, Vienna, Austria, http://www.R-project.org

Rewicz T, Grabowski M, MacNeil C, Bacela-Spychalska K (2014) The profile of a 'perfect' invader-the case of killer shrimp, Dikerogammarus villosus. Aquat Invasions 9:267-288
Ricciardi A, MacIsaac HJ (2000) Recent mass invasion of the North American Great Lakes by Ponto-Caspian species. Trends Ecol Evol 15:62-65

Ricciardi A, MacIsaac HJ (2011) Impacts of biological invasions on freshwater ecosystems. In: Richardson DM (ed) Fifty years of invasion ecology: the legacy of Charles Elton, 1st edn. Wiley Blackwell, Oxford, p 432

Roberts DW (2015). Ordination and multivariate analysis for ecology: R package labdsv, https://cran.r-project.org/web/ packages/labdsv

Sala OE, Chapin FS, Armesto JJ, Berlow E, Bloomfield J, Dirzo R, Huber-Sanwald E, Huenneke LF, Jackson RB, Kinzig A, Leemans R, Lodge DM, Mooney HA, Oesterheld M, LeRoy Poff N, Sykes MT, Walker BH, Walker M, Wall DH (2000) Global biodiversity scenarios for the year 2100 . Science 287:1770-1774

Schindler DW (1998) Replication versus realism: the need for ecosystem-scale experiments. Ecosystems 1:323-334

Schöll F (1990a) Erstnachweis von Chaetogammarus ischnus STEBBING im Rhein. Lauterbornia 5:71-74

Schöll F (1990b) Zur Bestandssituation von Corophlum curvispinum SARS im Rheingebiet. Lauterbornia 5:67-70

Schöll F, Balzer I (1998) Das Makrozoobenthos der deutschen Elbe 1992-1997. Lauterbornia 32:113-129

Schöll F, Fuksa J (2000) The makrozoobenthos of the Elbe. Land Water Manag Eur 2:9-12

Schöll F, Haybach H, Eggers TO (2015) Aquatische Neozoen in Fließgewässern. In: Hupfer M, Calmano W, Fischer H, Klapper H (ed) Handbuch Angewandte Limnologie: Strukturelle Veränderungen und Belastungen von Gewässern 32, Erg. Lfg. 2/15. Wiley-VHC, Weinheim, pp 1-24

Simberloff D, Von Holle B (1999) Positive interactions of nonindigenous species: invasional meltdown? Biol Invasions 1:21-32

Statzner B, Gore JA, Resh VH (1988) Hydraulic stream ecology: observed patterns and potential applications. J N Am Benthol Soc 7:307-360

Tittizer T, Schleuter A (1986) Eine neue Technik zur Entnahme quantitativer Makrozoobenthosproben aus Sedimenten größerer Flüsse und Ströme. Deutsche Gewässerkundliche Mitteilungen 30:147-149

Tittizer T, Schöll F, Dommermuth M (1994) The development of the macrozoobenthos in the River Rhine in Germany during the 20th century. Water Sci Technol 29:21-28

Tittizer T, Schöll F, Banning M, Haybach A, Schleuter M (2000) Aquatische Neozoen im Makrozoobenthos der Binnenwasserstraßen Deutschlands. Lauterbornia 39:1-72

Truhlar AM, Dodd J, Aldridge DC (2014) Differential leaf-litter processing by native (Gammarus pulex) and invasive (Dikerogammarus villosus) freshwater crustaceans under environmental extremes. Aquat Conserv 24:56-65

van Riel MC, van der Velde G, Rajagopal S, Marguillier S, Dehairs F, bij de Vaate A (2006) Trophic relationships in the Rhine food web during invasion and after establishment of the Ponto-Caspian invader Dikerogammarus villosus. Hydrobiologia 565:39-58

van Riel MC, van der Velde G, bij de Vaate A (2011) Dispersal of invasive species by drifting. Curr Zool 57:818-827 